Trivent Publishing

(C) The Authors, 2016

Available online at http://trivent-publishing.eu/

Series: Philosophy, Communication, Media Sciences

Volume: Communication Today: An Overview from Online Journalism to Applied Philosophy

\title{
The Historical-Dogmatic Impact of the Status of the Saint within the Christian Community
}

\author{
Iacob Coman \\ Pentecostal Theological Institute, Bucharest, iacob_coman@yahoo.com
}

\begin{abstract}
In the present study we propose an interdisciplinary and confessional comparative approach of the saint's status. Avoiding the controversy caused by the worship of saints, we will try to prove in this paper that throughout time, the entire life of the Christian community revolved around certain saints and was determined by them. The fundamentals of Christianity, or the continuation of the idea of God's people from Israel towards Christianity is accomplished by "that Holy who shall be born of you..." (Luke 1:35), that is through Jesus Christ. This divine quality with openness to the humanity of those who sought the service of God will be alive during the life of the Church and will determine its history and all dogmatic and faith formulas. Finally we propose a conciliation in the assessment and perception of Saints that determined the life of the Christian community. Christianity owes everything to its predecessors who, more or less appreciated, infused in the future the magnificence of God's love unfolded in Jesus Christ and transmitted to the Church and every man through the Holy Spirit.
\end{abstract}

\section{Keywords:}

Saint; dogma; holiness; church; saint office

This is an Open Access article distributed in accordance with the Creative Commons Attribution Non Commercial (CC-BY-NC-ND 4.0) license, which permits others to copy or share the article, provided original work is properly cited and that this is not done for commercial purposes. Users may not remix, transform, or build upon the material and may not distribute the modified material (http://creativecommons.org/licenses/by-nc/4.0/)

DOI: $10.22618 /$ TP.PCMS.20164.349023 
The issue of sanctity of life has always been controversial. And this is due to several factors among which we mention only those that directly concern us in our research. First, the idea of holiness is one of divine origin, both ontologically and from a normative point of view. This reality is clear from the records of the Holy Scriptures, such as: "But as He who has called you is holy, so be you holy in all manner of conversation." (1 Peter 1:15), "Be you holy; for I am holy" (1 Peter 1:16), etc. Secondly, throughout the history of Christianity, the Church was the one that created and administered the saint office. This happened due to the desire for recognition of life worshiped to God, which some believers achieved in an unusual way. In the third place, our appreciation of the fact that this topic is controversial, derives from the way the community of believers behaved throughout history in relation to those who have been recognized and canonized as saints.

In what follows we will briefly develop these three positions of the idea of holiness in order to understand more specifically and profoundly the historical and dogmatical impact that the office of those canonized had on the Christian community.

\section{God, Origin, and Standard of Holiness}

When we talk about the holiness of God, we must consider His statements on this divine quality and less the explanation that we are building. God's holiness and light should be regarded in the perspective of the dialectics and biblical dilemma. On the one hand they constitute the radical reality that separates us from God, and on the other hand these are required to prove we belong to God. The Bible speaks of God as the One "Who only has immortality dwelling in the light which no man can approach unto; Whom no man has seen, nor can see: to Whom be honour and power everlasting!" (1 Timothy 6:16) and the Bible says that all believers are "light of the world" (Matthew 5:14) and records situations where some believers have seen God.

This dilemma should not be speculated for God, God has no need of such favours. He is holy, "God's holiness comes from the mystery of His being, therefore it produces fear and trembling." At the same time this dilemma should not be speculated in favour of man, man does not need spiritual surpluses that are not covered by the reality. "The sanctification (of man), namely the consecration or separation for God's purposes in the world, comes by choice."2 This biblical dilemma through which man is separated from God and, at the same time, is placed in a deifying unity with Him, lets us know that there is an ontological holiness related to the nature of God, and which we cannot influence, and there is a normative holiness that we can appropriate from the ontological holiness through obedience. "Be you therefore perfect, even as your Father Who is in heaven is perfect." (Matthew 5:48)

These are the conditions through which some people have access to a life of holiness and then, by ecclesial demarches, they are canonized as saints.

In conclusion, historically and dogmatically, the office or status of saint derives from God's concern regarding the lives of those who are His. Under these circumstances, man, individually or institutionally, does not assign holiness to someone, but recognizes it.

\section{The Church, the Keeper of the Saint Office}

As anticipated, the second reality that brings the issue of sanctification and of holiness in the area of controversy is the reference to the Church. Schism, Reformation and Neoprotestantism have created so many currents on church dogma and regarding their authority in religious life and holiness. The controversial area loses sight, in general, of the fact that the Church is founded by Christ and its holiness derives from God's holiness. Making an analogy between the people of Israel and the Church, Boris Bobriskoy notes the following: "In the theology of Israel, Israel's holiness derives obviously from God's holiness. God is holy and holiness is expandable, is practicable... The Church is holy because God Himself sanctifies it..." Because of this reality, in view of objectivity regarding the impact of saints on the history and dogma of Christian community, the research on saints must be done especially in the area of the Bible, and not in the

\footnotetext{
${ }^{1}$ Ion Bria, Dicționar de teologie ortodoxă [Dictionary of Orthodox Theology], (Bucharest: Publishing House of the Mission and Bible Institute of the Romanian Orthodox Church, 1994), 344.

${ }^{2}$ Ibidem, 344

${ }^{3}$ Boris Bobrinskoy, Taina Bisericii [Le Mystère de la Trinité], (Alba-Iulia: Reîntregirea Publishing, 2004$), 165$.
} 
confessional one. This would create a framework for a dialogue which is fairer and less exclusivist. The martyrs who died in the name of Christ belong to Christianity as a whole, no matter which one of the Christian communities claims them or not. The Church is in the workshop of Jesus Christ Who works through His gifts "in order to present to Himself a glorious Church, not having spot, or wrinkle, or any such thing; but that it should be holy and without blemish." (Ephesians 5:27)

The authority of the Church for the establishment of the Office of saints and of the criteria for the canonization of the believers derives from its very holiness. "The holiness of the Church comes from its equivalent with the Body of Christ, in which the Spirit dwells. Its character which is "saint and sanctifying is not affected by the incompleteness of the believers..." ${ }^{4}$ What is important to note here is that the Church created the office and not the saints! Saints are the result of God's love and the Church recognizes them. "The canonization is carried out by an act of ecclesiastical power - ecumenical or local. The Source of holiness does not fail in the Church..." In other words, the act of recognition of the saints cannot and should not be limited. At a certain point all the members of the Church are saints.

Protestant and neoprotestant reluctance can be understood when it comes to the act of worship, but when it comes to a man whose life of holiness is recognized, the opinions need to be reworded. To canonize means "to pass, to put, to place a dedicated person among the saints," believer, a life that suggests an ideal towards which we all aim. This cannot be in any way reprehensible, but, on the contrary, evoking strengthens the faith of those who are on the path of Christ. The first step towards this recognition in the Roman-Catholic Church is beatification -- "beatification is proclaimed by the Supreme Pontiff, after a thorough examination of the life and writings proposed for canonization, considering that in these are not doctrines expressed contrary to Church doctrine or Christian perfection."

Concluding, we must emphasize that an important factor that infused the Church throughout its history and along its dogmatic formulations, was offered by the exemplary life of some believers, who were later called Saints, either canonized or who remained in the memory of the Christian community.

\section{The Christian Community, Attitudes, and Controversies regarding This "Office"}

In the following, I do not wish to fuel the religious polemics regarding the dogma on saints. The present study has a different purpose. If we only refer to Saint Gerard of Cenad, we should avoid the religious claiming in favour of Christian recognition. The Christian community must set itself to recognize its values, not to claim them at the expense of good Christian coexistence. Talking about the sanctity of all Christians, Ion Bria notes the following: "Christians are saints not simply by convention, but rather by the fact that they are placed in the communion of God through Jesus Christ." ${ }^{8}$ This introduction to the Community must be available to all Christians, otherwise the situation can become inappropriate. The confessional order should encourage this divine communality and, along with it, the magnificence of Christian fellowship. "Saints have been many and always exist, like the martyrs of the Church today; all of them have in common the fact that they love like Jesus and that they willingly offer their lives to God, like Him." 9 The attitude of the contemporary Christian community should start from this reality, a reality which requires the biblical text: "Let us therefore, as many as be perfect, be thus minded: and if in anything you be otherwise minded, God shall reveal even this unto you." (Philippians 3:15)

The contemporary Christian community must retrieve the Christian biblical unity of dogmatic history, and not rely on the Christian biblical separation of the same history. Discussing saints and their historicaldogmatic impact on the Christian community, we highlight that on the path of communion with Christ one has an obligation to remember forgiveness and the power to forgive - thus, one should not remember that we wrong each other.

In conclusion, regardless the Christian attitude and the controversy of the Christian community on denominational tones or theological currents, we must all agree that saints cannot be removed from Christian collective memory, even if they belong to "others."

\footnotetext{
${ }^{4}$ Ion Bria, Dicționar, 345 .

${ }^{5}$ Serghei Bulgakov, Ortodoxia [The Orthodox Church], (Bucharest: Paideia Publishing, 1994), 163-164.

${ }^{6}$ Ion M. Stoian, Dicționar religios [Religious Dictionary], (Bucharest: Garamond Pulbishing, 2007), 48.

7 Tertulian Langa, Dicționar teologic creștin din perspectiva ecumenismului catolic [Christian Theological Dictionary from a Catholic Ecumenism Perspective], (Cluj-Napoca: Dacia Publishing, 1997), 30.

${ }^{8}$ Ion Bria, Dicționar, 344.

${ }^{9}$ Tertulian Langa, Dicționar, 242.
} 


\section{New Testament Frameworks}

The first Christian community is the one of the New Testament. We perceive its birth as made by Jesus Christ through His Incarnation. However, there is an important detail showing that the idea of saints underlies the formation of the Christian community contemporary to Christ. The man, as saint, determines his historicity and the dogma of the New Testament. In the Gospel of Luke, the messenger who came from heaven identifies Jesus Christ as follows: "And the angel answered and said to her, The Holy Ghost shall come on you, and the power of the Highest shall overshadow you: therefore also that holy thing which shall be born of you shall be called the Son of God." (Luke 1:35) This is confirmed during Christ's trial, when Pilate's wife dreams something similar: "When he was set down on the judgment seat, his wife sent unto him, saying, Have thou nothing to do with that Just Man: for I have suffered many things this day in a dream because of Him." (Matthew 27:19) The framework of the New Testament, the message of the gospels, the very foundation of the Christian community were buit by a saint -- "Jesus was several times named the Holy One of God; Mark 1:24; Luke 4:34; John 6:69, etc." 10

The commentators of the New Testament usually neglect this detail, but we consider it vital. That Holy Who shall be born of you -- this title makes Christ equal to God at least as much as the title Son. Holiness is God's nature. As the cherubims stood above the throne of God, "one cried unto another, and said, Holy, holy, holy, is the Lord of hosts: the whole earth is full of His glory!" (Isaiah 6:3). In other words, holiness is a quality of God, a reality which cannot be found as such in any other being. In Mary's body, just like in a shrine, Someone of the same Godly quality is placed. It is not the idea of holiness which brings together the Christian community in the New Testament, but the one and only Saint and His saints. It is about quality as being, as a person, not as work or thing. Thus the appellation "holy" used later for saintly merits and the acts of some believers is not part of a human strategy, but is rather a divine manifestation that may reveal some people of existential divine quality, intimate to the existence of God, but not to be confused to God's Being. The idea of being saint does not have anything to do with the effort of doing something, but rather with the will of being someone. "The process of regeneration of the heart by the Holy Spirit marks the beginning of sanctification." 11 The believer opens to God to create a saint within him.

While Incarnated, Jesus Christ does not degenerate the divine character of His being, but He expresses it. This expression brings to life the human as saint; Saint John the Baptist, Saint John the Evangelist, Saint Paul, the Holy Apostles and many other "holy brethren" (Hebrews 3:1) who had, have or will experience a heavenly calling.

In conclusion, the frameworks of the New Testament are made by God around His saints. The impact of His identity and their identity represent the historical and dogmatic rhetoric of the entire New Testament -this rhetoric and dogmatism is generated in God's providence and have the purpose of God's self-revelation.

\section{Frameworks of the First Millennium}

Between the second century and the end of the first millennium, the Christian community followed the same pattern. The Church was the bodily manifestation of Christ, while the Saint represented the divine movement of the body. "And He is the head of the body, the Church." (Colossians 1:18) "Christ's divinehumanity is reproduced in the mystery of the Church, in its "self-sacramentality." In Christ and in the Church dwells all the fullness of the Godhead bodily (Colossians 2:9)" "12 This refers to holiness as someone not as something. This union between Christ and the Church obliges us to talk about the being of the Church. "The Church of Christ is not an institution; it is a new life with Christ and in Christ, led by the Holy Spirit... The Church is the Body of Christ, and it enters a living unit with Him... It is a union of two into one, that is neither dissolved into duality, nor absorbed into unity. The Church as the Body of Christ, is not Christ-Godthe Man; It only represents His humanity; It is life in Christ..."13 Referring to this issue, Apostle Paul wrote the following: "This is a great mystery - (but I speak concerning Christ and the Church)" (Ephesians 5:32). This refers to the reality through which the Church expresses itself and exists as a being, the reality

\footnotetext{
${ }^{10}$ Gerhard Meier, Comentariu biblic - Evanghelia după Luca [Bible Commentary - The Gospel of Luke], (Korntal:, Lumina Lumii Publishing, 1999), 42.

11 Melvin E. Dieter, Cinci concepții despre sfințire [Five Conceptions on Holiness], (Oradea: Cartea Creștină Publishing, 1999), 17.

${ }^{12}$ Boris Bobrinskoy, Taina, 40.

${ }^{13}$ Serghei Bulgakov, Ortodoxia, 9.
} 
connected to the mystery and loaded with divine mystery, of a "person" who can only understood in the light of God's mysterious work. The Church is, in this case, as Dumitru Stăniloae notes, the Mystery of all Mysteries.

Turning to the issue of our study, we see, in the first millennium, that the Church, i.e. the human part of the universalized body of Christ, is determined by the presence of the saints. Both on the level of martyrdom and internal controversies, God's holy people advocate and build dogmatics and the history of the Church. The period of the seven Ecumenical Councils is dominated by the presence and influence of the Church Holy Fathers. Starting with the First Council, where "Deacon Athanasius"14 or Saint Athanasius the Great holds a determining role in the oral arguments fighting against Arianism, one can notice that throughout the other councils, the impact of the ones considered saints is very important. "Saint Gregory of Nazianzus refuted the Pneumatomachi heretics with Saint Gregory of Nyssa." by "Saint Cyril in the Cathedral of the Virgin Mary of Ephesus ${ }^{16}$ and the list is completed throughout the patristic period, where we notice the historical and dogmatic impact that the status of the saint in the first millennium.

In conclusion, just as the intrinsic holiness of Christ encompasses the same quality as the Father, the intrinsic holiness of the Church and saints have same qualities as Christ. The religious life of Christians in the first millennium is marked by the life of saints on both a dogmatic level and a history-making level.

\section{The Frameworks of the Second Millennium}

The onset of the second millennium was precarious for Christians. The Church of Christ, as being, bled internally. "Leo IX sent his delegates Bishop of Silva Candida Umbreto and Stephen of Lorraine, abbot of Montecassino, to Byzantium. The Emperor welcomed them in a friendly manner, but the Patriarch excluded them from his community. Then they filed an excommunication bull on the altar of St. Sophia and left."17 The incident did not represent such a threat as it turned out later. Christianity was divided in two and the recognition of saints became a problem. The idea of the Fathers of the Eastern Church and those of the Western Church appeared in the history and Christianity and in Patristics.

This rift deepened and created the prerequisites for the fall of Constantinople. "The misunderstandings between Christians, the isolation of Constantinople from the West, the quarrels between unionists and antiunionists in Byzantium, the lack of military aid, ${ }^{18}$ etc. are events of which Mohammed II took advantage in order to conquer Constantinople. In these new conditions, the history of Christianity enrolled its saints differently. St. Thomas Aquinas particularized Western thought, and the fall of Constantinople led the East into an almost irrevocable slavery. Nevertheless, Christian life continued to revolve around those identified as saints. Their anonymity became more obvious, and the impact was no less than in the first millennium. "The saints are those who, through their active faith and love, have achieved the likeness of God and expressed the image of God in all his strength; those who called upon them the abundant grace." ${ }^{19}$ Believers of this kind continue to exist, both in the East and in the West, and even if their claim will be denominational, the Christian community owes its beauty to all who have joined this pantheon.

As East enters a shadow cone, the evolution of the West, instead of being positive, as one might expect it to be, is shook by the Reformation. "The Reformation period was full of turbulence and uncertainty. The Catholic Church, which guaranteed an undeniable unity in the Middle Ages, was now unable to do so." 20 Along with this, a significant number of Christians give up the worship of saints and deny the possibility of sanctification. In the Protestant and neo-Protestant Christian faith, Christians of great historical importance and great reformative power are born, thus leading to the disappearancethe appellative "saint" in favour of the commemoration of "a genius."

However, in retrospect, Jaroslav Pelikan notes that "most of the Christian denominations in the West, no less than Roman-Catholicism itself, can trace their existing doctrinal position in the conflict of the sixteenth

\footnotetext{
${ }^{14}$ Ioan Rămureanu, Istoria bisericească universală [Church History], (Bucharest: Publishing House of the Mission and Bible Institute of the Romanian Orthodox Church, 1992), 126.

${ }^{15}$ Ibidem, 129.

${ }^{16}$ Ibidem, 139.

${ }^{17}$ Ludwig Hertling S.J., Istoria Bisericii [Church History], (Ars Longa Publishing, 1998), 195.

${ }^{18}$ Ioan Rămureanu, Istoria, 351.

${ }^{19}$ Serghei Bulgakov, Ortodoxia, 161.

${ }^{20}$ Jonathan Hill, Istoria gândirii creștine [History of Christian Thought] (Oradea: Casa Cărții Publishing, 2007), 180.
} 
century..." ${ }^{21}$ This pluralism within the Christian community encourages and justifies the emergence of some denominational "Church Fathers."22

As we mentioned in the beginning, in this study we do not intend to fuel the inter-confessional Christian debate, but we tried to briefly describe the historical-dogmatic frameworks in which the Saints remain the landmark and the real impact in the development of the Church.

This historical reality can be nuanced, but cannot be changed. It remains the way it was conducted at the beginning. However, the contemporary context requires that technological trends accept a conciliatory perspective towards this pantheon of saints to promote Christ and His Holy Church.

The saint status marked the history of the Christian community and its dogmatic formulations. Forgetting that the lives of saints have been researched for centuries, each confessional Christian community was enriched with "the saints" of the other. The historical, dogmatic, and confessional contribution of every universalized Christian saint must be accredited by the entire Christian community.

\section{Modern and Contemporary Frameworks}

This sub-title will collect the modern and contemporary frameworks and perceptions of a single name: Saint Gerard of Cenad. The historical and dogmatic impact of this saint deserves the accreditation of time and the religious life that especially exists in the Romanian Banat region, as well as in Hungary and Europe in general.

Although there are a few still extant texts written by him, the perception of the Romanians of Banat, the Transylvanian Saxons, and the Hungarians in Banat, is of great importance. His activity, far from being onesided, is an activity which penetrates in a complex manner the society of his time and afterwards. Settled in Maroschburg, he claims ecclesial responsibility as being more complex than a simple service of the altar. "From this place, Gerard starts with the aid of several collaborators in order to establish the structures of a diocese, the building, preaching, teaching, founding parishes, raising and consecrating churches. Around his cathedral, he founded a school for training young indigenous clergy - and to this end he did not come empty-handed: in addition to the books necessary for liturgical use, St. Gerard wrote himself theological."23 All this activity recommends him to history and asks for gratitude from the contemporary modern society, which he marked positively in a Christian way, paying thus a debt which is worth the appellation of holiness.

In this context, we see how, on an individual level, the status of being saint determines historically and dogmatically the Christian community contemporary to the one concerned and those that follow him. The religious and social tenacity of St. Gerard of Cenad determines contemporary researchers to acquire his determination and to note these facts: "Among the lesser-known figures of medieval Hungary is, without a doubt, that of St. Gerard of Cenad, Saint Stephen's close collaborator and one of the most important ecclesiastical personalities who appeared during the establishment and consolidation of the Hungarian church institutions." 24

The modern and contemporary society cannot remain alien to the influence of St. Gerard of Cenad. One can see in this saint "... image of a complex and significant figure for Hungary's religious evolution, but also for medieval Transylvania." 25 This impact of the saint is more or less found in Transylvanian contemporary Christianity, a colourful Christianity, monolithic in substance. In line to the current ideas of intercultural education, in which attitudes are meant to be formed more than mere knowledge, Gerard recommended in the year 1000 that "the teacher (doctor) gave his efforts that no learner should remain unaccomplished. This is why he received the teaching gift (magisterium), so to teach in school (schola) the best of teachings (exerceat disciplina) which come out of science (doctrina), more in order to learn good behaviour (virtutium eruditio) rather than to combine beautiful words." 26 These concerns of St. Gerard of Cenad around the year 1000 are more than modern, they are contemporary and target laws on the vocation and professional conscience that should characterize us in the future.

\footnotetext{
${ }^{21}$ Jaroslav Pelikan, Tradiția creștină [The Christian Tradition], vol. IV (Iasi: Polirom, 2006), 53.

${ }^{22}$ Ibidem, 53.

23 Orizonturi culturale italo-române (Italian-Romanian Cultural Horizons), Bilingual Intercultural Magazine no. 12/December 2015, $5^{\text {th }}$ year, http://www.orizonturiculturale.ro/ (last time accessed: March 5, 2016).

24 Marian Horvat, Caiete silvane, http://www.caietesilvane.ro/indexcs.php?cmd=articol\&idart=2504 (last time accessed: March 5, 2016).

${ }^{25}$ Ibidem.

${ }^{26}$ Maria Micle, Filosofia Sfântului Gerard de Cenad în context cultural şi biografic [St. Gerard of Cenad's Philosophy in Cultural and Biographical Context], ed. Claudiu Mesaroş (Szeged: 2013, JATE Press), 190.
} 
In conclusion, in this study we tried to offer a different assessment of the Christian life. Determined by the purpose of a life and not strictly by the religious identity, we could argue that historically and dogmatically, the Christian community was determined along its two-thousand-year history by God's saints. The paradigm set forth by the Saint born from the Virgin Mary resisted as matrix and method by which the history and dogma of the Christian community were formulated and made contemporary in every century through the lives of the saints.

\section{Bibliography}

Bria, Ion. Dicționar de teologie ortodoxă (Dictionary of Orthodox Theology). Bucharest: Publishing House of the Mission and Bible Institute of the Romanian Orthodox Church. 1994.

Bobrinskoy, Boris. Taina Bisericii (Original title, Le Mystère de la Trinité). Alba-Iulia: Reîntregirea Publishing, 2004.

Bulgakov, Serghei. Ortodoxia (Original title, The Orthodox Church). Bucharest: Paideia Publishing, 1994.

Dieter E., Melvin. Cinci concepții despre sfințire (Five Ideas on Holiness). Oradea: Cartea Creștină Publishing. 1999.

Hertling, Ludwig, S.J. Istoria Bisericii (Church History). Ars Longa Publishing, 1998.

Hill, Jonathan. Istoria gândirii creștine (History of Christian Thought). Oradea: Casa Cărții Publishing, 2007.

Horvat, Marian. Caiete silvane, http://www.caietesilvane.ro/indexcs.php?cmd=articol\&idart=2504 (last time accessed: March 5, 2016).

Langa, Tertulian. Dicționar teologic creștin din perspectiva ecumenismului catolic (Christian Theological Dictionary from a Catholic Ecumenism Perspective). Cluj-Napoca: Dacia Publishing, 1997.

Meier, Gerhard. Comentariu biblic - Evanghelia după Luca (Bible Commentary - The Gospel of Luke). Volumes 4 and 5. Korntal: Lumina Lumii Publishing, 1999.

Mesaroş, Claudiu (ed.). Filosofia Sfântului Gerard de Cenad în context cultural şi biografic (St. Gerard of Cenad's Philosophy in Cultural and Biographical Context). Szeged: JATE Press Publishing, 2013.

Orizonturi culturale italo-române (Italian-Romanian Cultural Horizons). Bilingual Intercultural Magazine no. 12/December 2015, $5^{\text {th }}$ year, http://www.orizonturiculturale.ro/ (last time accessed March 5, 2016)

Pelikan, Jaroslav. Tradiția creștină (Christian Tradition), vol. IV. Iasi: Polirom Publishing, 2006.

Rămureanu, Ioan. Istoria bisericească universală (Church History). Bucharest: Publishing House of the Mission and Bible Institute of the Romanian Orthodox Church, 1992.

Stoian, M. Ion. Dicționar religios (Religious Dictionary). Bucharest: Garamond Publishing, 2007. 